\title{
Penguatan Pembelajaran Daring di SDN Jakasampurna V Kota Bekasi, Jawa Barat Menggunakan Media Pembelajaran Interaktif Berbasis Augmented Reality (AR)
}

\author{
Aisyah Herlina Arrum ${ }^{1}$, Syifaul Fuada ${ }^{2 *}$ \\ ${ }^{1}$ Pendidikan Guru Sekolah Dasar, Universitas Pendidikan Indonesia \\ ${ }^{2}$ Sistem Telekomunikasi, Universitas Pendidikan Indonesia \\ *Email: Syifaulfuada@upi.edu
}

\begin{abstract}
ABSTRAK
Kurangnya penggunaan media pembelajaran selama proses pembelajaran daring tak jarang menyebabkan minat dan juga motivasi peserta didik mulai menurun dengan merasakan kejenuhan dalam belajar. Penggunaan media pembelajaran interaktif dalam pembelajaran daring dapat dimanfaatkan sebagai peluang untuk meningkatkan minat dan motivasi belajar peserta didik. Kegiatan ini bertujuan untuk menguatkan pembelajaran daring melalui penggunaan media pembelajaran interaktif berbasis Augmented Reality bagi peserta didik Sekolah Dasar. Program ini merupakan bentuk dari Kuliah Kerja Nyata Tematik Pencegahan dan Penanggulangan Dampak Corona Virus Disease (KKNT PPD Covid-19) Universitas Pendidikan Indonesia di bidang Pendidikan. Metode dalam kegiatan pengabdian masyarakat yang dilaksanakan berupa sosialisasi secara daring melalui aplikasi Whatsapp Group. Kegiatan dilaksanakan pada tanggal 1 Desember 2020. Materi yang digunakan dalam media pembelajaran mengenai pengenalan mata uang rupiah Indonesia. Lokasi sosialisasi berada di SDN Jakasampurna V, Jalan Anggrek Raya, Kecamatan Bekasi Barat, Kota Bekasi, Jawa Barat. Sasaran program KKNT ini adalah peserta didik kelas III sebanyak 10 orang. Hasil dari KKNT ini menunjukkan bahwa penggunaan media pembelajaran interaktif berbasis Augmented Reality menumbuhkan rasa kesenangan dan minat belajar peserta didik di tengah pandemi Covid-19. Selain itu dengan memanfaatkan media pembelajaran interaktif peserta didik dapat mengetahui teknologi yang sedang berkembang.
\end{abstract}

Kata kunci: Covid-19, KKN Tematik UPI, Pembelajaran Daring, Media Pembelajaran Interaktif, Augmented Reality

\section{ABSTRACT}

The lack of learning media avaliable for online learning are often reduce the students interest and motivation caused by the boredom. The use of the interactive learning media on online learning could have a chance to increase students interest and motivation. The goal of this activity is to strengthen the online interactive learning based on augmented reality for elementary school student. This program is a form of the Universitas Pendidikan Indonesia on educational field Student Study Service about prevention and precaution of the Corona Virus Disease (KKNT PPD Covid-19). The method of this Student Study Service is implemented online via Whatsapp Group. The activity began on Desember 1st 2020. The theory used in the learning media is the introduction of Rupiah as the Indonesian currency. The socialization held on SDN Jakasampurna V, Jalan Anggrek Raya, Kecamatan Bekasi Barat, Kota Bekasi, West Java. The aim of this KKNT are $103 r d$ class student. Result shows that the use of interactive learning media based on Augmented Reality increase the student's enjoyment and interest amid the covid-19. Furthermore by using the interactive learning media, the students could understand the developed technology.

Keywords: Covid-19, KKN Tematik UPI, Online Learning, Interactive Learning Media, Augmented Reality 


\section{PENDAHULUAN}

Di Indonesia, penyebaran virus Covid-19 begitu cepat. Dalam mengantisipasi akan penularan virus tersebut, pemerintah mengeluarkan beberapa kebijakan yang menuntut masyarakat untuk stay at home. Akibatnya, aktivitas yang semula dilakukan secara luring, kini dilakukan secara daring. Kebijakan ini juga mengarah kepada proses pembelajaran di sekolah mulai dari jenjang usia dini hingga tingkat perguruan tinggi. Dari kondisi tersebut, lembaga pendidikan berusaha untuk tetap menjalankan kegiatan belajar mengajar, di mana melakukan inovasi pembelajaran salah satunya dengan bentuk pembelajaran secara online atau daring. Hal ini diperkuat dengan Menteri Pendidikan dan Kebudayaan Republik Indonesia terkait Surat Edaran Nomor 4 Tahun 2020 tentang Pelaksanaan Kebijakan Pendidikan dalam Masa Darurat Penyebaran Covid-19 (Astini ; Atsani, 2020).

Inovasi pembelajaran daring yang diterapkan pada masa pandemi ini bertujuan agar ketercapaian dalam kegiatan belajar mengajar tetap berjalan sebagaimana mestinya. Ketercapaian akan tujuan pendidikan dipengaruhi oleh sebagian faktor diantaranya pendidik, peserta didik, lingkungan dan perangkat pembelajaran (Yuliono dkk., 2018). Salah satu faktor yang perlu dikembangkan yaitu perangkat pembelajaran menggunakan media pembelajaran yang inovatif dan lebih bermakna. Sejalan dengan pendapat yang diungkapkan oleh Sukiman (2012) bahwa media pembelajaran merupakan sesuatu yang dapat dipakai guna menyampaikan pesan oleh pengirim kepada penerima sehingga memicu pikiran, perasaan, perhatian dan minat serta keinginan peserta didik dalam rangka mewujudkan tujuan pembelajaran secara efektif (dalam Mustaqim, 2016). Hal lain juga disampaikan oleh Soenarto (dalam Istiqlal, 2017) yang menyatakan bahwa interaktif merupakan suatu proses pemberdayaan peserta didik guna mengendalikan lingkungan belajar. Pengembangan media pembelajaran interaktif sangat penting untuk meningkatkan motivasi belajar anak. Ketertarikan anak-anak terhadap aktifitas digital dapat dimanfaatkan sebagai peluang untuk meningkatkan motivasi anak dalam belajar melalui penggunaan media pembelajaran interaktif. Di era modern ini, media pembelajaran yang mulai dikembangkan salah satunya yaitu media pembelajaran menggunakan Augmented Reality (AR). Augmented Reality merupakan pengembangan teknologi yang dapat menggabungkan suatu objek 3 dimensi kemudian memproyeksikan benda maya tersebut dalam waktu nyata. Menampilkan objek 3D yang seakan-akan ada pada lingkungan nyata menjadi daya tarik Augmented Reality ini (Iksan \& Djuniadi, 2017).

Media pembelajaran interaktif berbasis Augmented Reality ini dianggap dapat meningkatkan minat dan motivasi peserta didik. Hal ini berkaitan dengan penelitian yang dilakukan oleh Minaldi (2019) menunjukkan bahwa pemanfaatan media pembelajaran interaktif berbasis Augmented Reality melalui aplikasi Assemblr mampu meningkatkan kemampuan berpikir kreatif peserta didik. Aplikasi Assemblr yang menyajikan Augmented Reality ini dapat diimplementasikan pada kegiatan pembelajaran melalui smartphone sehingga memberikan kesan pembelajaran yang menarik bagi peseta didik. Berdasarkan segitiga pengalaman Edgar Dale di mana kegiatan observing dapat memberikan tingkat pemahaman peserta didik sebanyak $50 \%$ dari apa yang mereka lihat dan baca (Minaldi, 2019). Menurut CEO Assemblr Hasbi Asyadiq aplikasi ini merupakan sebuah platform Augmented Reality untuk memudahkan pengguna dalam mendesain konten $3 \mathrm{D}$ yang divisualisasikan ke dalam bentuk AR dengan sederhana dan dalam waktu yang lebih cepat (Anwar, 2020).

SDN Jakasampurna V Kota Bekasi merupakan salah satu sekolah dasar negeri yang berada pada Jalan Anggrek Raya, Kecamatan Bekasi Barat, Kota Bekasi, Jawa Barat. Sekolah dasar tersebut sudah menerapkan kebijakan pembelajaran daring. Namun pada pelaksanaannya belum optimal yang diantara salah satu faktornya yaitu kurangnya penggunaan media pembelajaran sebagai penunjang kegiatan belajar 
mengajar secara daring. Selama ini, guru hanya memberikan pembelajaran melalui link youtube tanpa adanya timbal balik langsung kepada peserta didik. Oleh karena itu, pada kegiatan KKNT pelaksana membuat program sosialisasi penggunaan media pembelajaran interaktif berbasis Augmented Reality dari aplikasi Assemblr melalui Whatsapp Group. Sosialisasi ini bertujuan untuk menguatkan pembelajaran daring peserta didik agar memberikan kesan yang menyenangkan dalam kegiatan belajar mengajar online. Sasaran pada program ini yaitu peserta didik kelas III yang di mana penggunaan media pembelajaran interaktif berbasis Augmented Reality di sekolah tersebut merupakan yang pertama kali dilakukan sebagai penunjang pembelajaran daring. Materi yang disajikan mengenai mata uang rupiah guna memudahkan peserta didik dalam mengenali mata uang rupiah Indonesia beserta nama tokoh pahlawan yang di dalamnya juga terdapat nama kebudayan Indonesia. Hal ini sejalan dengan pembahasan materi yang sedang diajarkan yaitu mengenai mata uang rupiah.

\section{BAHAN DAN METODE}

Bentuk dari kegiatan pengabdian masyarakat yang dilaksanakan yaitu berupa sosialisasi penggunaan media pembelajaran interaktif berbasis Augmented Reality menggunakan aplikasi Assemblr sebagai penunjang pembelajaran daring selama pandemi Covid-19 kepada peserta didik kelas III SDN Jakasampurna V Kota Bekasi. Metode yang dilakukan adalah sosialisasi secara daring melalui aplikasi Whatsapp Group. Kegiatan dilaksanakan pada hari Selasa, 1 Desember 2020 yang di mana termasuk dalam kegiatan KKNT PPD Covid-19 yang dimulai dari 17 November - 17 Desember 2020. Peserta didik yang diikutsertakan sejumlah 10 orang. Dalam kegiatan ini dilakukan penyampaian seperti yang disajikan pada Gambar 1. mengenai langkahlangkah meng-install aplikasi Assemblr di Play Store berkenaan dengan media pembelajaran interaktif berbasis Augmented Reality melalui video tutorial yang telah dibuat dan mengarahkan peserta didik untuk mengakses link media pembelajaran interaktif Augmented Reality yaitu materi mengenal mata uang rupiah Indonesia di Whatsapp Group. Pemilihan materi sejalan dengan pelajaran yang sedang dibahas yaitu mengenal mata uang. Penggunaan aplikasi Assemblr sebagai media pembelajaran interaktif karena objek yang disediakan cukup beragam, seperti objek aksesoris rumah, kendaraan, hewan, menginput gambar dari perangkat smartphone sendiri, tulisan 3D dan lain sebagainya. Sehingga pengguna dapat bebas berkreasi sesuai kebutuhan. Pada akhir kegiatan, disediakan kuesioner evaluasi berupa link google form yang dapat diisi oleh peserta didik untuk mengetahui minat anak dalam pembelajaran daring menggunakan media pembelajaran interaktif berbasis Augmented Reality melalui Whatsapp Group. Dokumentasi ditujukan pada Gambar 2.

\section{HASIL}

A. Hasil Pelaksanaan Kegiatan

Hasil dari kegiatan sosialisasi ini adalah peserta didik kelas III SDN Jakasampurna $\mathrm{V}$ Kota Bekasi dapat membangun antusias, minat serta motivasi dalam pembelajaran daring. Peserta didik mengetahui bagaimana cara menggunakan aplikasi Assemblr yang berbasis Augmented Reality untuk menampilkan objek 2D atau 3D yang diproyeksikan. Terdapat pilihan mode "View 3D" dan "View AR" yang dapat diakses oleh peserta didik seperti yang ditujukan pada Gambar 3. Pengetahuan baru yang sebelumnya tidak dimiliki peserta didik dalam penggunaan media pembelajaran interaktif berbasis Augmented Reality. Memudahkan pemahaman materi dalam pembelajaran daring mengenai mata uang rupiah Indonesia. Selain itu, guru pun turut termotivasi dan mendapatkan referensi alternatif penggunaan media pembelajaran interaktif untuk pembelajaran daring yang belum diketahui akan sampai kapan berlangsung. 


\section{B. Evaluasi Program}

Evaluasi hasil kegiatan sosialisasi penguatan pembelajaran daring menggunakan media pembelajaran interaktif berbasis Augmented Reality melalui aplikasi Assemb/r menunjukkan bahwa dengan menggunakan media pembelajaran tersebut peserta didik cukup terbantu dalam memahami materi dari pembelajaran daring seperti yang disajikan pada Gambar 4 dan 5. Penggunaan media pembelajaran interaktif yang ditujukan dalam Gambar 6. merupakan kegiatan yang menyenangkan. Menurut salah satu peserta didik seperti yang ditujukan pada Gambar 7. bahwa media pembelajaran interaktif berbasis Augmented Reality melalui aplikasi Assemblr merupakan hal yang sangat seru, peserta didik berhasil mencoba media pembelajaran mengenal mata uang rupiah Indonesia menggunakan mode "View AR". Dalam penggunaannya, peserta didik tidak terdapat kesulitan, sehingga hal ini menambah minat belajar selama pembelajaran daring. Dokumentasi ditujukan pada Gambar 8 dan 9. Hasil keseluruhan evaluasi dari responden disajikan melalui Grafik 1.

\section{Analisis Faktor Pendukung dan Penghambat}

Dalam suatu kegiatan terdapat faktor pendukung dan penghambat ketika pelaksanaan. Faktor pendukung dari kegiatan penguatan pembelajaran daring menggunakan media pembelajaran interaktif berbasis Augmented Reality yaitu pengetahuan. Pengetahuan menjadi bagian penting guna menyajikan sesuatu untuk diimplementasikan. Selain itu, komunikasi yang baik agar berjalannya koordinasi untuk merealisasikan apa yang sudah direncanakan. Baik menjalin komunikasi dan koordinasi dengan pihak sekolah maupun sasaran kegiatan.

Sedangkan faktor penghambat yang terdapat pada pelaksanaan diantaranya perangkat atau smartphone sasaran kegiatan yang kurang mendukung untuk menginstall aplikasi $A R$, jaringan internet yang kurang stabil, respon cepat dari sasaran kegiatan ketika membagikan media pembelajaran, serta waktu yang cukup singkat dari tahap persiapan kegiatan sampai evaluasi kegiatan. Namun tidak menutup kemungkinan bahwa sosialisasi penggunaan media pembelajaran interaktif berbasis Augmented Reality melalui aplikasi Assemb/r ini bisa tetap berjalan sebagaimana mestinya.

\section{PEMBAHASAN}

Dalam menguatkan pembelajaran daring di tengah pandemi Covid-19, penggunaan media pembelajaran interaktif berbasis Augmented Reality melalui aplikasi Assemblr membantu meningkatkan minat belajar dan memberi kesan pembelajaran yang lebih menarik untuk peserta didik. Berdasarkan hasil evaluasi kegiatan menunjukkan adanya peningkatan ketertarikan peserta didik dalam proses belajar menggunakan media pembelajaran interaktif berbasis Augmented Reality. Hal ini sesuai dengan penelitian Pramono dan Setiawan (2019) yang menunjukkan bahwa 86\% dari 30 responden anak-anak menyatakan aplikasi yang dikembangkan berbasis Augmented Reality sangat efektif sebagai media pengenalan buah-buahan. Selain itu, penelitian yang dilakukan oleh January (2019) menunjukkan bahwa pengembangan media pembelajaran berbasis Augmented Reality termasuk ke dalam kategori sangat valid, layak dan efektif digunakan. Berdasarkan hasil uji kelayakan menurut ahli media total presentase sebesar $90 \%$, uji kelayakan ahli materi sebesar $88,46 \%$, sedangkan dalam penerapan media pembelajarannya mampu meningkatkan nilai rata-rata kelas menjadi $89,24 \%$.

Pada masa pencegahan dan penanggulangan dampak Covid-19 yang mengharuskan seluruh satuan pendidikan untuk menerapkan pembelajaran dari rumah atau daring. Hal ini menjadi pemicu kurangnya keaktifan peserta didik dalam pembelajaran daring. Namun, hal tersebut dapat diminimalisir oleh kegiatan 
pembelajaran daring melalui media pembelajaran interaktif. Sejalan dengan penelitian yang dilakukan oleh Nurhayati (2020) menunjukkan peningkatan keaktifan peserta didik sebesar $73,9 \%$ dari penggunaan media game edukasi quiziz dalam pembelajaran daring pada mata pelajaran IPS.

Inovasi pembelajaran yang kini terus berkembang menjadi tugas masyarakat dalam menyesuaikan proses pembelajaran daring. Mempelajari akan teknologi atau media pembelajaran bagi masyarakat baik pendidik maupun peserta didik yang digunakan dapat dilakukan secara otodidak. Hal ini menjadi tuntutan guna mewujudkan pembelajaran daring yang efektif, inovatif dan bermakna. Sehingga pembelajaran daring yang dilakukan pada masa pandemi Covid-19 ini, tidak memberikan kesan yang menjenuhkan bagi satuan pendidikan karena penggunaan media pembelajaran interaktif yang bervariasi.

\section{KESIMPULAN DAN SARAN}

Berdasarkan hasil kegiatan sosialisasi di SDN Jakasampurna V Kota Bekasi, Jawa Barat dapat disimpulkan bahwasanya aplikasi Assemblr yang dijadikan media pembelajaran interaktif berbasis Augmented Reality menunjukkan adanya penguatan pembelajaran daring di tengah pandemi Covid-19. Melalui media pembelajaran interaktif tersebut, terlihat peserta didik sangat antusias dan merasa senang dalam kegiatan pembelajaran daring. Peserta didik dapat mengetahui dan memahami materi mengenai mata uang rupiah Indonesia, sehingga media pembelajaran interaktif berbasis Augmented Reality dapat dikatakan sangat efektif dan memberikan inovasi pembelajaran pada sekolah tersebut. Beberapa hal yang perlu disarankan guna menguatkan penggunaan media pembelajaran interaktif berbasis Augmented Reality pada masa pandemi ini diantaranya penyajian materi yang menarik serta variatif yang disesuikan dengan sasaran satuan pendidikan. Pengembangan media pembelajaran interaktif tidak hanya terfokus pada medianya saja, namun kejelasan materi yang menjadi keberhasilan media pembelajaran tersebut sehingga peserta didik dapat memahaminya dengan baik. Kegiatan sosialisasi ini perlu ditindaklanjuti guna memberikan pengetahuan serta penguatan bagi para satuan pendidik dalam memfasilitasi pembelajaran daring.

\section{UCAPAN TERIMA KASIH}

Terima kasih diberikan kepada 1) LPPM Universitas Pendidikan Indonesia, 2) Kepala Sekolah beserta Guru SDN Jakasampurna V Kota Bekasi, 3) Responden kegiatan sosialisasi, dan 4) Pelaksana KKNT PPD Covid-19 tahap II 2020.

\section{DAFTAR PUSTAKA}

Anwar, F. (2020, April 13). Hasbi Asyadiq: Berkreasi dengan Teknologi AR | youngster.id. https://youngster.id/technopreneur/hasbi-asyadiq-berkreasi-dengan-teknologiarl

Astini, N. K. S. (2020). Pemanfaatan Teknologi Informasi dalam Pembelajaran Tingkat Sekolah Dasar pada Masa Pandemi Covid-19. LAMPUHYANG, 11(2), 13-25. https://doi.org/10.47730/jurnallampuhyang.v11i2.194

Atsani, L. G. M. Z. (2020). Transformasi Media Pembelajaran Pada Masa Pandemi Covid19. AL-HIKMAH: Jurnal Studi Islam, 1(1). http://webcache.googleusercontent.com/search?q=cache:wZYA57Ss2UgJ:ejo urnal.kopertais4.or.id/sasambo/index.php/alhikmah/article/view/3905+\&cd=1\& $\mathrm{hl}=\mathrm{id} \& \mathrm{ct}=\mathrm{clnk} \& \mathrm{gl}=\mathrm{id}$

Iksan, N., \& Djuniadi. (2017). Media Pembelajaran Interaktif Berbasis Augmented Reality (AR) Untuk Meningkatkan Motivasi Belajar Anak. ITEJ (Information Technology Engineering Journals), 02(01), 4. https://doi.org/10.24235/itej.v2i1.15 
Istiqlal, M. (2017). Pengembangan Multimedia Interaktif Dalam Pembelajaran Matematika. JIPMat, 2(1), 43-54. https://doi.org/10.26877/jipmat.v2i1.1480

January, D. O. (2019). Pengembangan Augmented Reality Materi Alat Pencernaan Manusia Siswa Kelas V Sd Muhammadiyah Program Khusus Ampel Kecamatan Ampel Kabupaten Boyolali Tahun 2018. [Thesis. Salatiga: Pascasarjana IAIN Salatiga].

http://webcache.googleusercontent.com/search?q=cache:QAhpAR9WggAJ:erepository.perpus.iainsalatiga.ac.id/5481/+\&cd=1\&hl=id\&ct=clnk\&gl=id

Minaldi, I. (2019). Efektivitas Pemanfaatan Media Pembelajaran Interaktif Berbasis Aplikasi Assemblr Untuk Meningkatkan Kemampuan Berpikir Kreatif. [Skripsi. Bandung: Universitas Pendidikan Indonesia]. http://repository.upi.edu/40667/

Mustaqim, I. (2016). Pemanfaatan Augmented Reality Sebagai Media Pembelajaran. Jurnal Pendidikan Teknologi dan Kejuruan, 13(2), 10. http://dx.doi.org/10.23887/jptk-undiksha.v13i2.8525

Nurhayati, E. (2020). Meningkatkan Keaktifan Siswa Dalam Pembelajaran Daring Melalui Media Game Edukasi Quiziz pada Masa Pencegahan Penyebaran Covid-19. Jurnal Paedagogy, 7(3), 145. https://doi.org/10.33394/jp.v7i3.2645

Pramono, A., \& Setiawan, M. D. (2019). Pemanfaatan Augmented Reality Sebagai Media Pembelajaran Pengenalan Buah-Buahan. INTENSIF: Jurnal IImiah Penelitian dan Penerapan Teknologi Sistem Informasi, 3(1), 54. https://doi.org/10.29407/intensif.v3i1.12573

Yuliono, T., Sarwanto, \& Rintayati, P. (2018). Keefektifan Media Pemelajaran Augmented Reality Terhadap Penguasaan Konsep Sistem Pencernaan Manusia. Jurnal Pendidikan Dasar, 9(1), 65-84. https://doi.org/10.21009/10.21009/JPD.081

\section{LAMPIRAN}

Berikut gambar yang didokumentasikan saat pelaksanaan Pengabdian Masyarakat berupa sosialisasi media pembelajaran interaktif dalam penguatan pembelajaran daring di SDN Jakasampurna V Kota Bekasi, Jawa Barat menggunakan media pembelajaran interaktif berbasis Augmented Reality.

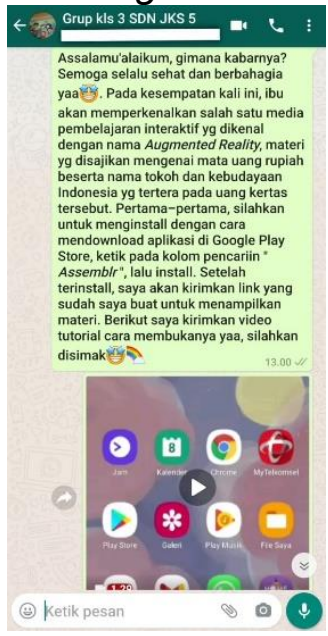

(a)

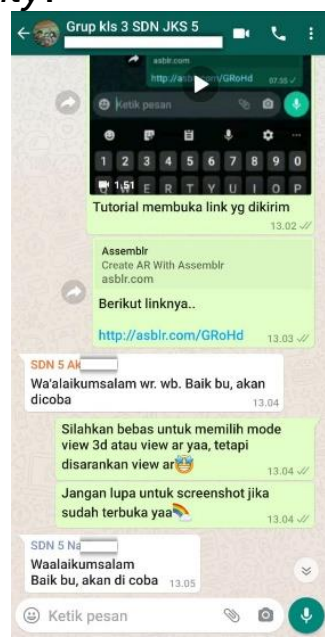

(b)

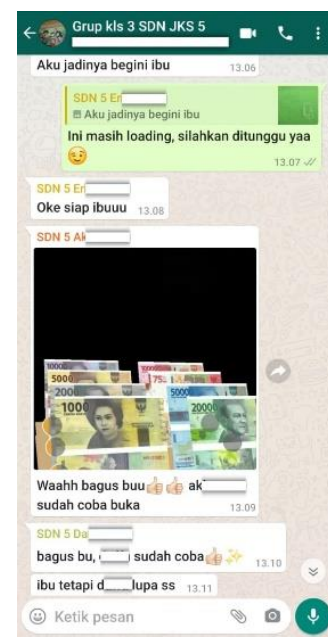

(c)

Gambar 1. Tampilan (a) Pelaksana memberikan penjelasan beserta video cara meng-install aplikasi Assemb/r, (b) Membagikan video cara membuka link Augmented Reality dari aplikasi Assemblr, (c) Respon peserta didik ketika mencoba aplikasi Assemblr. 


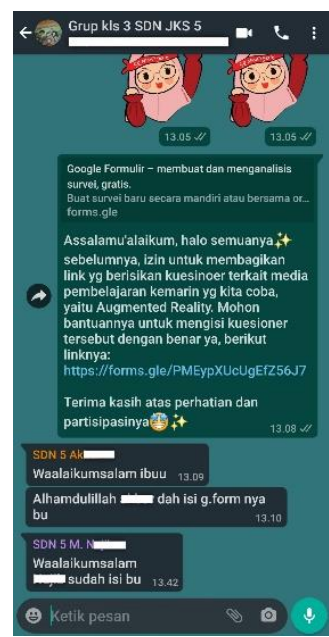

Gambar 2. Membagikan link evaluasi berupa kuesinoer di Whatsapp Group

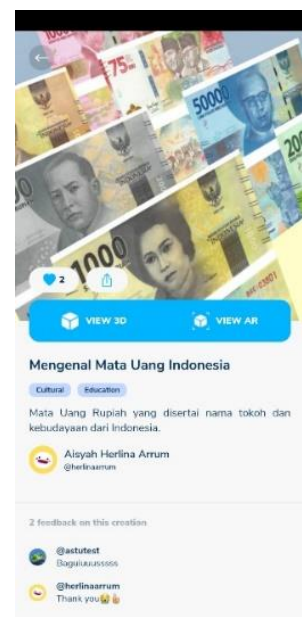

(a)

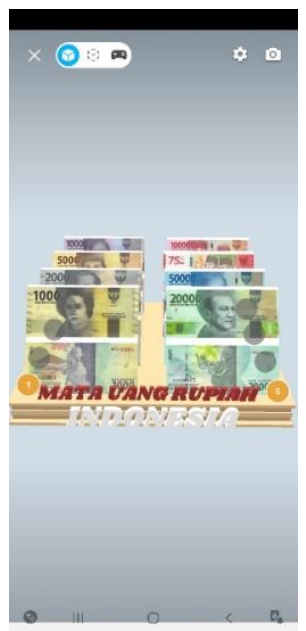

(b)

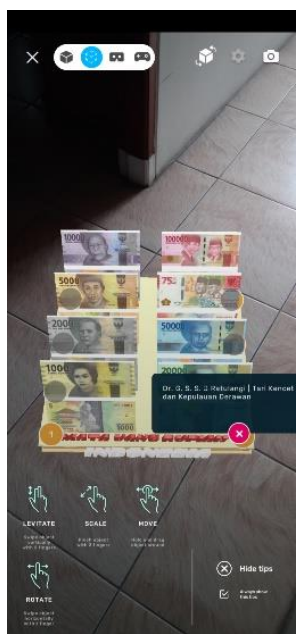

(c)

Gambar 3. (a) Tampilan beranda materi, (b) Tampilan mode "View 3D" dan (c) mode "View AR" pada aplikasi Assemblr.
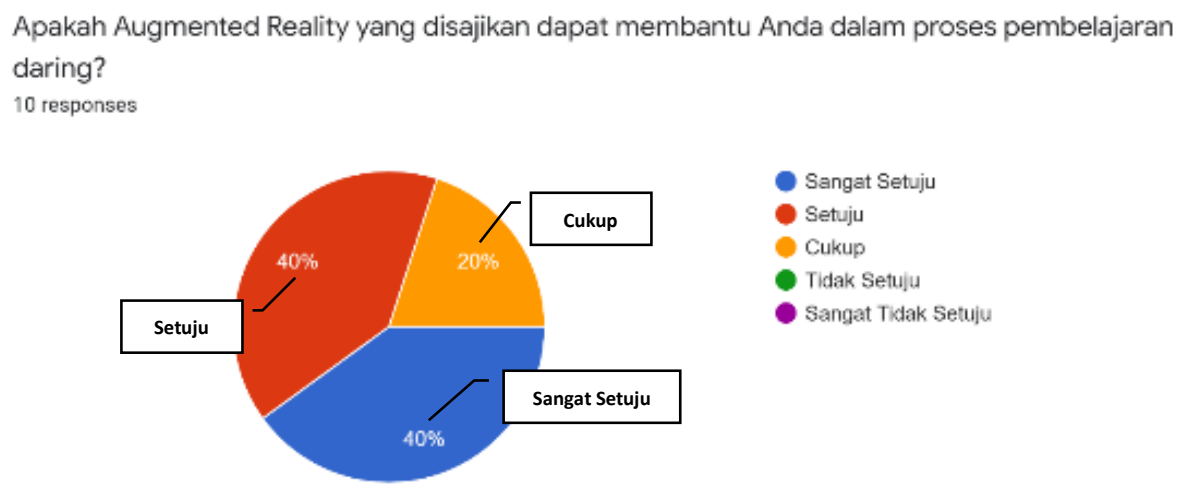

Sangat Setuju

Setuju

Cukup

Tidak Setuju

- Sangat Tidak Setuju

Gambar 4. Pertanyaan pertama mengenai penggunaan media pembelajaran dapat membantu proses pembelajaran daring 
Apakah Augmented Reality dapat membantu Anda memahami materi yang dipelajari? 10 responses
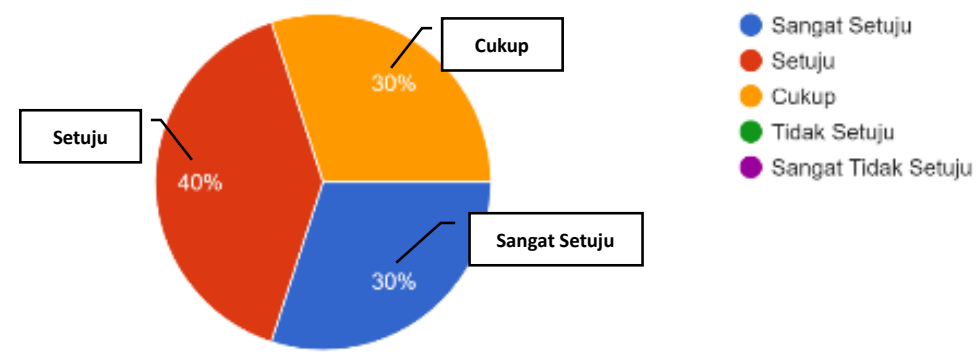

Gambar 5. Pertanyaan kedua mengenai pemahaman materi berbantuan media pembelajaran

Apakah Augmented Reality merupakan media pembelajaran yang menyenangkan?
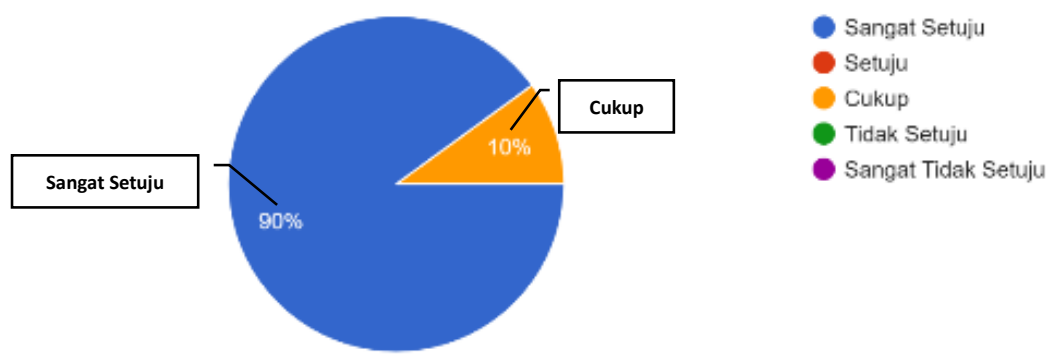

Gambar 6. Pertanyaan ketiga mengenai media pembelajaran yang menyenangkan

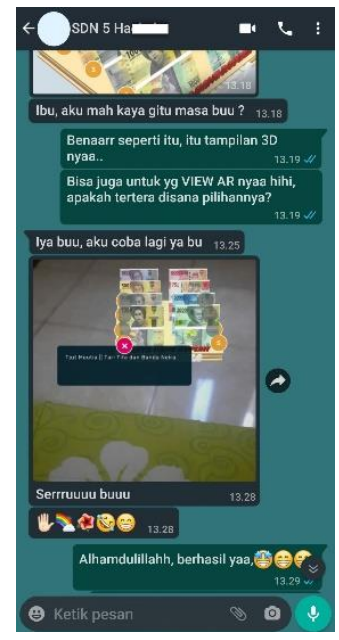

(a)

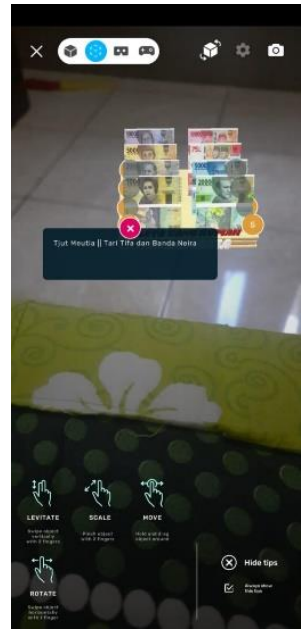

(b)

Gambar 7. (a) Respon salah satu peserta didik yang mencoba media pembelajaran, (b) Tampilan peserta didik berhasil membuka dan menggunakan aplikasi Assemblr berbasis Augmented Reality 
Apakah terdapat kesulitan dalam penggunaan Augmented Reality? 10 responses

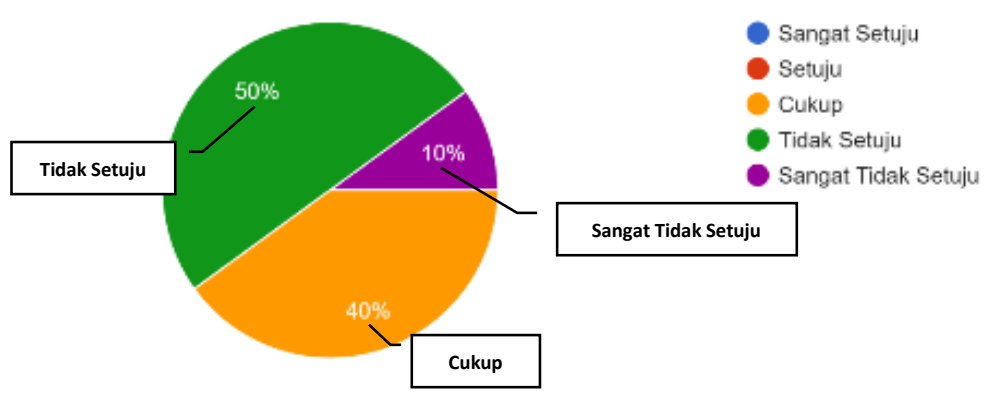

Gambar 8. Pertanyaan keempat mengenai kesulitan dalam penggunaan media pembelajaran

Apakah Augmented Reality menambah minat belajar Anda selama pembelajaran daring? 10 responses

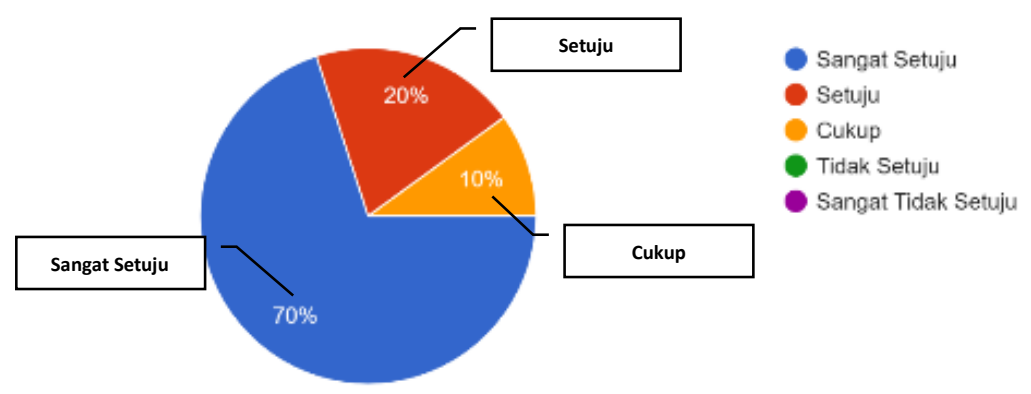

Gambar 9. Pertanyaan kelima mengenai peningkatan minat belajar dalam penggunaan media pembelajaran.

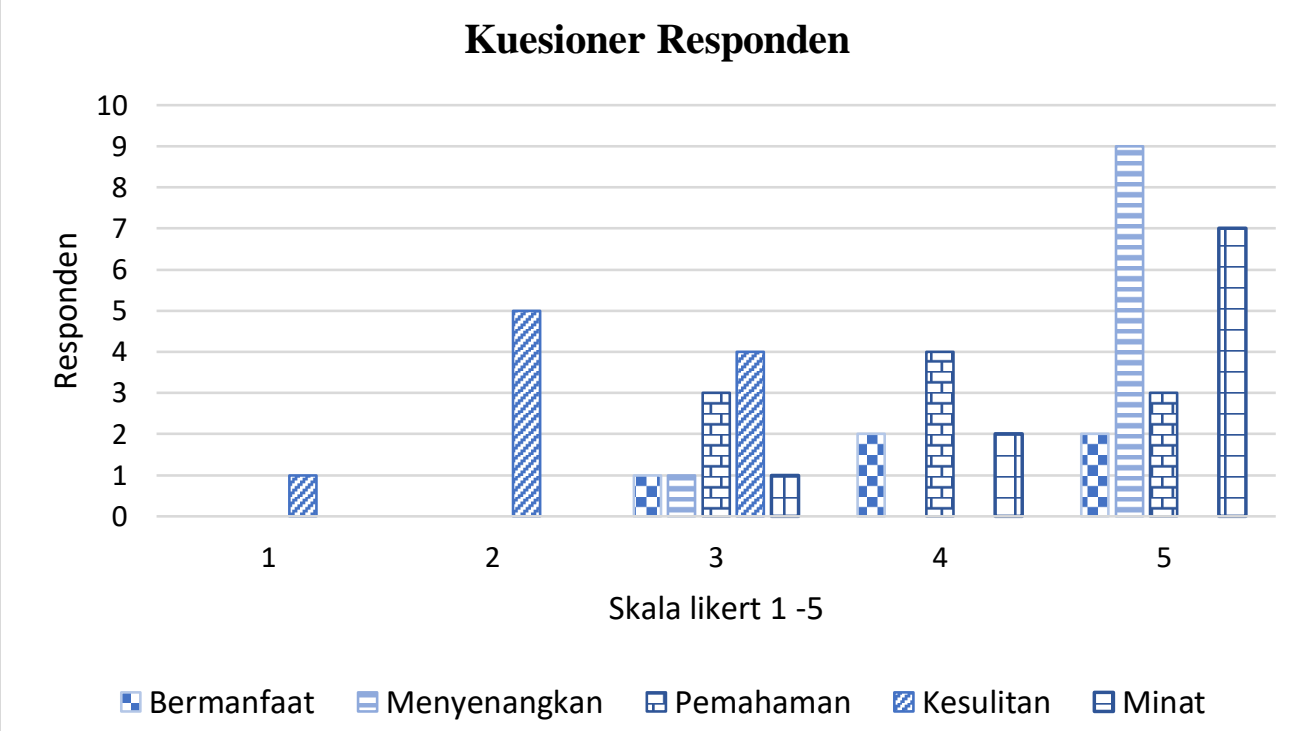

Grafik 1. Hasil kuesioner peserta didik menggunakan media pembelajaran AR. 